\title{
Composition and Larvicidal Activity of Essential Oil of Eugenia candolleana DC. (MYRTACEAE) against Aedes aegypti
}

\author{
Neves, I. A.; Rezende, S. R. F.; Kirk, J. M.; Pontes, E. G.; de Carvalho, M. \\ G.*
}

Rev. Virtual Quim., 2017, 9 (6), 2305-2315. Data de publicação na Web: 22 de dezembro de 2017

http://rvq.sbq.org.br

\section{Composição e Atividade Larvicida do Óleo Essencial de Eugenia candolleana DC. (MYRTACEAE) contra o Aedes aegypti}

Resumo: O mosquito Aedes aegypti é o vetor do vírus da dengue, Chikungunya e Zika. O aumento da resistência dos mosquitos a inseticidas comerciais prejudica programas de controle regulares; portanto, a prospecção química de espécies de plantas com propriedade larvicida tem sido uma alternativa para o controle deste vetor. O óleo essencial de Eugenia candollena DC foi obtido através do método de hidrodestilação, utilizando um aparelho tipo Clevenger modificado, sendo seus constituintes identificados utilizando a cromatografia a gás acoplada à espectrometria de massas e quantificados pela cromatografia gasosa. O óleo obtido foi rico em sesquiterpenos, demonstrando o $\beta$-elemeno $(35,87 \pm 0,13 \%)$ como componente majoritário. A mortalidade das larvas do A. aegypti foi de $100 \%$ em $24 \mathrm{~h}$ após o tratamento com o óleo na concentração de $0,50 \mu \mathrm{g} \cdot \mu \mathrm{L}^{-1}$ e a $\mathrm{CL}_{50}$ para este tempo foi estimado em 0,30 $\mu g \cdot \mu L^{-1}$.

Palavras-chave: Larvicida; CG-EM; sesquiterpenos; $\mathrm{CL}_{50}$; Aedes; CG-EM.

\section{Abstract}

The mosquito Aedes aegypti is the vector of the dengue, Chikungunya and Zika virus. The increasing resistance of mosquitoes to commercial insecticides impairs regular control programs; therefore, chemical prospecting of plant species with larvicidal properties has been an alternative for the control of this vector. The essential oil of Eugenia candollena DC was obtained through the hydrodistillation method, using a modified Clevenger-type apparatus, being its constituents identified using gas chromatography-mass spectrometry and its constituents were quantified by gas chromatography. The oil proved rich in sesquiterpenes, containing $\beta$-elemene $(35.87 \pm 0.13 \%$ ) as major component. Aedes aegypti larvae mortality rate of $100 \%$ was obtained after $24 \mathrm{~h}$ of treatment with the oil at concentrations of $0.50 \mu \mathrm{g} . \mu \mathrm{L}^{-}$ ${ }^{1}$ and the $\mathrm{LC}_{50}$ at this time was estimated to be $0.30 \mu \mathrm{g} \cdot \mu \mathrm{L}^{-1}$.

Keywords: Larvicidal; GC-MS; Sesquiterpenes; $\mathrm{LC}_{50}$; Aedes aegypti.

* Universidade Federal Rural do Rio de Janeiro, Instituto de Ciências Exatas, Departamento de Química, BR 465, km 7, CEP. 23890-000, Seropédica-RJ, Brasil.

$M$ mgeraldo@ufrri.br

DOI: 10.21577/1984-6835.20170138

Rev. Virtual Quim. |Vol 9| | No.6| |2305-2315| 


\title{
Composition and Larvicidal Activity of Essential Oil of Eugenia candolleana DC. (MYRTACEAE) against Aedes aegypti
}

\author{
Ilzenayde de A. Neves, Sabrina R. da F. Rezende, Juliana M. Kirk, \\ Emerson G. Pontes, Mário G. De Carvalho*
}

Universidade Federal Rural do Rio de Janeiro, Instituto de Ciências Exatas, Departamento de Química, BR 465, km 7, CEP. 23890-000, Seropédica-RJ, Brasil.

* mgeraldo@ufrri.br

1. Introduction

2. Experimental

2.1. Plant material

2.2. Essential oil extraction

2.3. Gas chromatography analysis

2.4. Gas chromatography-mass spectrometry analysis

2.5. Component identification

2.6. Larvicidal activity test

\section{Results and Discussion}

\section{Conclusions}

\section{Introduction}

The mosquito Aedes aegypti L. (Diptera: Culicidae) acts as a vector for various viruses, such as dengue, yellow fever, Chikungunya and the newcomer Zika, being considered by the World Health Organization as one of the major public health problems in the world. ${ }^{1,2}$ The most widely adopted strategy to reduce the incidence of these diseases is to control the population of mosquito larvae. In view of the damage caused by dengue in the country, it is considered of paramount importance to find new methods to combat this vector. Plants naturally present defense mechanisms; therefore, material extracted from plant species has traditionally been used for controlling pest species of insects. ${ }^{3-5}$ The control activities have detected mosquito resistance to chemical insecticides; therefore, the use of essential oils and plant extracts is gaining prominence as an alternative means of control of insect vectors. Additionally, they are not harmful to the environment. ${ }^{6}$

Essential oils consist of special volatile metabolites characterized by a strong odor and generally have a lower density than water. Oils are lipophilic in nature with a proven ability to interfere with metabolic, biochemical, physiological and behavioral functions in insects. ${ }^{7}$ 
The Myrtaceae family has been recognized for investigations regarding the chemical composition of their species and biological activities, mainly due to the presence of essential oils, making Eugenia candolleana DC a potential plant in larvicidal control. Eugenia candolleana DC., popularly known as "murta", "murtinha", "ameixa-damata" and "cereja-roxa" is a rare species of the Eugenia genus frequently found in Brazilian rainforests of the northwest, whose ripening fruit presents a dark purple appearance, with a slightly sweet and firm flesh. There are few studies related to this species in the literature, ${ }^{8,9}$ although the infusion of its leaves has been popularly used to treat pain and fever. ${ }^{9}$

Therefore, the purpose of this study was to evaluate the chemical characterization and the ability of the essential oil of $E$. candolleana DC. to control Aedes aegypti.

\section{Experimental}

\subsection{Plant material}

Eugenia candolleana leaves were collected in the morning in the city of Seropédica - RJ, Brazil, Campus of the Universidade Federal Rural do Rio de Janeiro (UFRRJ) in July 2014, and identified by the Forest Engineer, Gabriel Pinto Rodrigues Gonçalves. A voucher specimen of the plant is placed in the herbarium RBR UFRRJ under RBR $n^{\circ} 36910$.

\subsection{Essential oil extraction}

Fresh leaves $(300.00 \pm 0.15 \mathrm{~g})$ of $E$. candolleana were subjected to hydrodistillation for $2 \mathrm{~h}$ using a modified Clevenger apparatus, the dimensions used in the equipment used do not interfere with the reproducibility of the data. Leaves were crushed and deposited in the distillation flask $(6 \mathrm{~L})$ along with $3500 \mathrm{~mL}$ of distilled water, and when the process was completed, the essential oil was separated from the water by decanting and dried with anhydrous sodium sulfate. The extracted essential oils were packed in an amber glass bottle at $4{ }^{\circ} \mathrm{C}$ and protected from light. The essential oil yield was calculated and expressed in weight of oil per weight of fresh leaves. The analyses were performed in triplicate.

\subsection{Gas chromatography analysis}

Quantitative analyses were performed using a chromatograph with gas equipped with a flame ionization detector (GC-FID) using a HP-5890 series II apparatus. The analyses were performed with a capillary column Factor Four-VF-5MS (30 m x 0.25 nm in diameter $\times 0.25 \mathrm{~mm}$ film thickness); at temperature programming $60{ }^{\circ} \mathrm{C}$ to $260{ }^{\circ} \mathrm{C}$ ( 3 ${ }^{\circ} \mathrm{C} \cdot \mathrm{min}^{-1}$ ), then $10{ }^{\circ} \mathrm{C}$ to $290{ }^{\circ} \mathrm{C} \cdot \mathrm{min}^{-1}$; gun temperature of $220{ }^{\circ} \mathrm{C}$; interface temperature of $310{ }^{\circ} \mathrm{C}$ and detector of 280 ${ }^{\circ} \mathrm{C}$. Helium was used as carrier with a flow rate of $1.0 \mathrm{~mL} . \mathrm{min}^{-1}$, split ratio $1: 30$ and 1.0 $\mu \mathrm{L}$, the injected essential oil was diluted in dichloromethane. The analyses were performed in triplicate. Results were subjected to descriptive statistical analysis using the Statistical Analysis Software program. ${ }^{10}$

\subsection{Gas chromatography-mass spectrometry analysis}

Qualitative analysis was performed using a gas chromatography system coupled to mass spectrometry (Shimadzu GC-MS, GC17A / QP2010 Plus) with ion source to $220^{\circ} \mathrm{C}$ and impact energy of $70 \mathrm{eV}$, and the same experimental conditions were maintained as in gas chromatography. Fragments were analyzed in the scan range of $\mathrm{m} / \mathrm{z} 40-500$. The relative amount (\%) of each component oil was expressed the peak area as a percentage the total peak area of the oil. 


\subsection{Component identification}

The identification of essential oil components was performed by determination of their retention index (RI), calculated using the equation of Van den Dool \& $\mathrm{Kratz}^{11}$ for each constituent by injecting a series of linear hydrocarbon standards $\left(\mathrm{C}_{8}-\mathrm{C}_{40}\right)$ and the sample under the same conditions and comparing the result with the tabulated value, followed by confirmation of visual mass spectral patterns reported in the literature ${ }^{12}$ and the library's database. ${ }^{13}$

\subsection{Larvicidal activity test}

Bioassays were developed using the methodology recommended by the World Health Organization. ${ }^{14-16}$ The population of $A$. aegypti strain Rockefeller was maintained in the laboratory at $27 \pm 1{ }^{\circ} \mathrm{C}$ with a relative humidity of $70 \pm 5 \%$. Eggs were placed to hatch in a plastic pot with $1 \mathrm{~L}$ of dechlorinated water. After hatching, larvae were fed daily with fish food (Nutriflakes, Nutriconpet). The larvicidal activity assay was performed in quadruplicate in $50 \mathrm{~mL}$ plastic cups into which were added ten 3rd instar larvae in $10 \mathrm{~mL}$ of dechlorinated water. The essential oil was diluted in an aqueous solution of $2 \%$ dimethylsulfoxide (DMSO; Isofar) and distributed among the cups at concentrations of $0.08,0.15,0.25,0.30,0.35$ and $0.50 \mu \mathrm{g} \cdot \mu^{-1}$. Larval mortality was checked after $24 \mathrm{~h}$ of exposure to these concentrations the oil. A time course test was performed for the concentration of 0.50 $\mu \mathrm{g} . \mathrm{LL}^{-1}$ (higher mortality in $24 \mathrm{~h}$ ) where larval mortality was observed 1, 2, 4, 6, 12 and $24 \mathrm{~h}$ after exposure to oil and a second test for the concentration of $0.30 \mu \mathrm{g} \cdot \mathrm{\mu L}^{-1}\left(\mathrm{LC}_{50}\right)$ observed $1,6,24$ and $48 \mathrm{~h}$ after exposure to the oil. Parallel controls were included with water and 2\% DMSO. The GraphPad Prism ${ }^{\circledR} 5.0$ program was used to calculate the percent mortality and the $\mathrm{LC}_{50}$ (defined as the oil concentration required to kill $50 \%$ of the larvae in $24 \mathrm{~h}$ ) was calculated by Probit analysis using the BioStat professional 5.8.0 program. ${ }^{17}$

\section{Results and Discussion}

The yield of essential oil from $E$. candolleana leaves was $0.82 \pm 0.02 \%$. The chemical composition of the essential oil is shown in Table 1 . In all, 28 chemical constituents were identified, corresponding to approximately $94.77 \pm 0.36 \%$ of the oil's total content. This essential oil is composed primarily of sesquiterpenes (94.21\%). The $\beta$ elemene component $(35.87 \pm 0.13 \%$ ) (a) was identified as the major constituent, followed by $\delta$-elemene $(8.28 \pm 0.02 \%)$ (b) $\beta$ caryophyllene $(8.15 \pm 0.08 \%) \quad$ (c) and viridiflorene $(6.96 \pm 0.05 \%)$ (d) (Figure 1). The study by Nakamura et $a l^{8}$ demonstrated a chemical profile similar to that featured in this study, showing sesquiterpenes as the major components identified in the essential oil of $E$. candolleana leaves, but $\beta$-elemene was not identified in the chemical composition of the oil with $\delta$-elemene (13.87 $\pm 0.18 \%)$ as the major component. It is considered that variations in the chemical composition of the essential oil of the same species from different regions may be attributed to differences in geographical and climate parameters, such as temperature, altitude, wind direction, rainfall, soil type, etc. ${ }^{18}$ These soil and climatic conditions may explain the observed differences between our study and that of Nakamura et $a l^{8}$ In the previous study, the species of interest was collected in the summer (January), while the one described herein was collected in winter (July); both were from the Atlantic Forest region.

In other species of Eugenia genus, accounts of $\beta$-elemene as a major component are rare, Ramos et al. ${ }^{19}$ and Apel et $a .^{20}$ describe $\beta$-elemene (22.1 and $10.6 \%$, respectively) as major constituent in the 
essential oil of E. punicifolia collected in the Carapebus forest on the southeast coast of Brazil, and essential oil of $E$. ramboi collected in southern Brazil, respectively. Brun et al. ${ }^{21}$ identified this constituent among the majority, but not as the main essential oil of E. uniflora leaves, while Stefanello et $a l^{22}$ reports the presence of $\beta$-elemene as only $1 \%$ of the chemical composition of the essential oil from E. pyriformis.

Table 1. Average percentage of essential oil components from the leaves of Eugenia candolleana

\begin{tabular}{|c|c|c|c|c|c|}
\hline No. $^{a}$ & Compound & $\mathrm{RI}^{\mathrm{b}}$ & $\mathrm{RI}^{\mathrm{c}}$ & $\begin{array}{c}\text { Relative amount } \\
\quad \%^{\mathrm{d}} \pm S D^{\mathrm{e}}\end{array}$ & $\begin{array}{l}\text { Relative amount } \\
\quad \% d \pm \mathrm{SD}^{\mathrm{e}} \\
\text { Nakamura et al. }{ }^{8}\end{array}$ \\
\hline 1 & 3(Z)-Hexenol & 854 & 850 & $0.05 \pm 0.01$ & \\
\hline 2 & Isopentyl acetate & 857 & 869 & $0.07 \pm 0.00$ & \\
\hline 3 & 3-p-Menthene & 990 & 984 & $0.08 \pm 0.01$ & \\
\hline 4 & 1-p-Menthene & 1010 & 1021 & $0.03 \pm 0.00$ & \\
\hline 5 & Limonene & 1010 & 1024 & $0.14 \pm 0.02$ & \\
\hline 6 & Allyl Hexanoate & 1075 & 1079 & $0.09 \pm 0.01$ & \\
\hline 7 & Linalool & 1103 & 1095 & $0.09 \pm 0.02$ & \\
\hline 8 & $\delta$-Elemene & 1343 & 1335 & $8.28 \pm 0.02$ & \\
\hline 9 & $\beta$-Elemene & 1406 & 1389 & $35.87 \pm 0.13$ & \\
\hline 10 & $\beta$-Cariophyllene & 1432 & 1417 & $8.15 \pm 0.08$ & \\
\hline 11 & $\alpha$-Humulene & 1464 & 1452 & $1.42 \pm 0.02$ & \\
\hline 12 & 9-epi-(E)-Cariophyllene & 1484 & 1464 & $1.55 \pm 0.01$ & \\
\hline 13 & Ishwarane & 1493 & 1465 & $5.00 \pm 0.02$ & \\
\hline 14 & $\beta$-Selinene & 1502 & 1489 & $5.31 \pm 0.01$ & \\
\hline 15 & Viridiflorene & 1510 & 1496 & $6.96 \pm 0.05$ & \\
\hline 16 & Germacrene A & 1525 & 1508 & $4.44 \pm 0.03$ & \\
\hline 17 & $\delta$-Amorphene & 1529 & 1511 & $1.04 \pm 0.05$ & \\
\hline 18 & $\gamma$-Cadinene & & 1513 & & $0.90 \pm 0.04$ \\
\hline 19 & $\delta$-Cadinene & & 1519 & & $2.83 \pm 0.08$ \\
\hline 20 & Zonarene & & 1530 & & $0.33 \pm 0.00$ \\
\hline 21 & $\alpha$-Cadinene & & 1533 & & $0.47 \pm 0.00$ \\
\hline 22 & $\alpha$-Calacorene & & 1534 & & $0.67 \pm 0.00$ \\
\hline 23 & Elemol & & 1544 & & $0.17 \pm 0.00$ \\
\hline 24 & Germacrene B & 1569 & 1559 & $0.84 \pm 0.03$ & \\
\hline 25 & Maaliol & & 1562 & & $0.78 \pm 0.00$ \\
\hline 26 & Spathulenol & & 1577 & & $4.88 \pm 0.02$ \\
\hline 27 & Cariophyllene oxide & 1590 & 1582 & $1.05 \pm 0.03$ & \\
\hline 28 & Globulol & 1594 & 1590 & $0.74 \pm 0.02$ & $5.52 \pm 0.02$ \\
\hline 29 & Viridiflorol & 1597 & 1592 & $0.50 \pm 0.01$ & $4.25 \pm 0.03$ \\
\hline 30 & Rosifoliol & 1607 & 1600 & $0.99 \pm 0.01$ & $0.95 \pm 0.01$ \\
\hline 31 & Guaiol & & 1600 & & $0.39 \pm 0.00$ \\
\hline 32 & $\beta$-Atlanol & & 1607 & & $0.78 \pm 0.02$ \\
\hline 33 & 1,10-Di-epi-cubenol & & 1611 & & $0.78 \pm 0.00$ \\
\hline 34 & Junenol & & 1614 & & $0.90 \pm 0.00$ \\
\hline 35 & 1-epi-Cubenol & & 1621 & & $7.59 \pm 0.02$ \\
\hline $\operatorname{Rev}$ & $\mid$ Vol 9| |No.6| & 315 & & & 2309 \\
\hline
\end{tabular}




\begin{tabular}{|c|c|c|c|c|c|}
\hline 36 & Muurola-4,10(14)-dien-1 $\beta$-ol & & 1624 & & $8.68 \pm 0.02$ \\
\hline 37 & Citronellyl pentanoate & 1630 & 1624 & $0.90 \pm 0.04$ & \\
\hline 38 & $\gamma$-Eudesmol & 1640 & 1630 & $0.73 \pm 0.03$ & $0.36 \pm 0.01$ \\
\hline 39 & epi-Cubenol & & 1631 & & $0.36 \pm 0.01$ \\
\hline 40 & cis-Cadin-4-en-7-ol & 1648 & 1635 & $3.99 \pm 0.01$ & \\
\hline 41 & epi- $\alpha$-Muurolol & & 1638 & & $3.50 \pm 0.01$ \\
\hline 42 & $\alpha$-Muurolol & & 1642 & & $3.53 \pm 0.01$ \\
\hline 43 & Cubenol & 1662 & 1645 & $1.54 \pm 0.02$ & \\
\hline 44 & $\alpha$-Cadinol & & 1650 & & $5.26 \pm 0.01$ \\
\hline 45 & Pogostol & 1667 & 1651 & $0.43 \pm 0.01$ & \\
\hline 46 & (E)-10,11-Dihydroathantone & & 1666 & & $0.53 \pm 0.02$ \\
\hline 47 & $\beta$-Athantone & & 1666 & & $0.53 \pm 0.02$ \\
\hline 48 & Selin-11-en-4 $\alpha$-ol & 1678 & 1658 & $4.46 \pm 0.01$ & \\
\hline 49 & Eudesma-4(15),7-dien-1 $\beta$-ol & 1682 & & & $1.03 \pm 0.12$ \\
\hline \multicolumn{6}{|c|}{ Chemical group } \\
\hline & Unsaturated aliphatic alcohol & & & $0.05 \pm 0.01$ & \\
\hline & Aliphatic esters & & & $0.16 \pm 0.01$ & \\
\hline & Monoterpene hydrocarbons & & & $0.26 \pm 0.04$ & \\
\hline & Oxygenated monoterpenes & & & $0.09 \pm 0.02$ & \\
\hline & Sesquiterpenes hydrocarbons & & & $78.87 \pm 0.26$ & \\
\hline & Oxygenated sequiterpenes & & & $15.34 \pm 0.10$ & \\
\hline & Total identified & & & $94.77 \pm 0.36$ & \\
\hline & Unidentified & & & $5.26 \pm 0.28$ & \\
\hline
\end{tabular}

${ }^{a}$ Order of elution is given on VF-5MS; ${ }^{b} \mathrm{RI}$ indicates the retention indices that were calculated against C8-C40 n-alkanes on VF-5MS column; ${ }^{C} \mathrm{RI}$ indicates values reported in the literature for the VF-5MS; ${ }^{d}$ relative amount determined as the peak area relative to the total peak area; ${ }^{\mathrm{S}}$ Standard deviation.<smiles>C=C(C)C1CCC(C(=C)C)C(C(=C)C)C1</smiles>

$\beta$-Elemene (a)<smiles>C=C(C)C1C=C(C(C)C)CCC1C(=C)C</smiles>

$\delta$-elemene (b)<smiles>C=C1CC/C=C(/C)CCC2C1CC2(C)C</smiles>

$\beta$-cariophyllene (c)<smiles>CC1=C2CCC(C)C2C2C(C1)C2(C)C</smiles>

Viridiflorene (d)

Figure 1. Structures of majoritary substances in essential oil from the leaves of Eugenia candolleana

The biological test showed that the percent larval mortality caused by the essential oil of E. candolleana reached $100 \%$ after $24 \mathrm{~h}$ of treatment at concentration of $0.50 \mu \mathrm{g} \cdot \mu^{-1}$. The concentration of $0.50 \mu \mathrm{g} \cdot \mu \mathrm{L}^{-}$ ${ }^{1}$ was significantly more efficient than the other concentrations and the control group
(Figure 2a). This result is the first report of larvicidal activity of $E$. candolleana against larvae of $A$. aegypti. Based on this result, we evaluated the larvicidal activity of the essential oil of $E$. candolleana through a cronological test, in which larval mortality was analysed 1, 2, 4, 6, 12 and $24 \mathrm{~h}$ after 
exposure to the oil at a concentration of 0.50 $\mu g . \mu L^{-1}$ (Figure $2 b$ ).

We can highlight that the highest concentration that killed $100 \%$ of the larvae in $24 \mathrm{~h}$ is also able to kill approximately $50 \%$ of the larvae between 2 and $4 \mathrm{~h}$ (Figure $2 \mathrm{~b}$ ). Larvae from the control groups with water and $2 \%$ DMSO displayed zero mortality during the experiment. The DMSO used in the dilution of the oil caused no mortality, indicating that it influenced neither larval development nor death of the larvae in the treated groups. Several studies have been developed with the objective of evaluating the potential insecticide plant species, in the search for new substances that can be used as a vector controls, especially in A. aegypti. The most studied family is the Myrtaceae, ${ }^{23-34}$ representing $13.5 \%$ of active oils, while studies on species of Lamiaceae and Rutaceae represent $10.5 \%$ and $8.2 \%,{ }^{35}$ respectively. According to Sukumar et al., ${ }^{36}$ Regnault-Roger ${ }^{37}$ and Park et al., ${ }^{32}$ Myrtaceae species, have great potential for use as insecticides. Studies by Magalhães et al., ${ }^{38}$ Aciole et $a .^{39}$ and Lima et $a l^{40}$ obtained results that showed high larvicidal activity of an essential oil rich in oxygenated sesquiterpenes. Lima et al. ${ }^{40}$ correlated the activity of $L$. seriguela essential oil with high concentrations of these compounds in the mixture. Simas et al. ${ }^{41}$ observed that sesquiterpenes were more effective than oxygenated monoterpenes and phenylpropanoids against the larvae of $A$. aegypti. As reported by several authors, the oxygenated sesquiterpenes exhibit effective activity against $A$. aegypti larvae, but no reports showed sesquiterpenes hydrocarbons with larvicidal activity, such as those identified in the present study. Usually, the activity of an essential oil correlates with those of its major components. However, these special metabolites, through synergism/antagonism, may facilitate interactions that increase or decrease the larvicidal activity of the oils tested in comparison with the activities of the isolated constituents. ${ }^{42}$ According to the data obtained in this study after $24 \mathrm{~h}$, the median lethal concentration ( $\left(\mathrm{CC}_{50}-24 \mathrm{~h}\right)$ of the essential oil from $E$. candolleana was 0.30 $\mu \mathrm{g} \cdot \mu \mathrm{L}^{-1}$ (300 mg. $\mathrm{L}^{-1}$ ) (Figure 2c, 2d).

As the WHO has not established standard criteria to determine the larvicidal activity of natural products, we are faced with a conflict in the literature since there is no definite pattern with regard to $\mathrm{LC}_{50}$. Cheng et al. ${ }^{43}$ consider the following concentration $\mathrm{LC}_{50}>$ $100 \mathrm{mg} . \mathrm{L}^{-1}$ are not active, $\mathrm{LC}_{50}<100 \mathrm{mg} . \mathrm{L}^{-1}$ are active, and those with $\mathrm{LC}_{50}<50 \mathrm{mg} \cdot \mathrm{L}^{-1}$ are highly active. Kiran et al. ${ }^{46}$ consider compounds with $\mathrm{LC}_{50}<100 \mathrm{mg} \cdot \mathrm{L}^{-1}$, to be significantly larvicidal. Other authors have developed their own criteria to characterize the power of larvicidal activity of natural products, ${ }^{23,44,38}$. However, Komalamisra et al. ${ }^{45}$ considered products with $\mathrm{LC}_{50}<50 \mathrm{mg} . \mathrm{L}^{-1}$ active, those with $50 \mathrm{mg} \cdot \mathrm{L}^{-1}<\mathrm{LC}_{50}<100 \mathrm{mg} \cdot \mathrm{L}^{-1}$ moderately active, those with $100 \mathrm{mg} \cdot \mathrm{L}^{-1}$ $<\mathrm{LC}_{50}<750 \mathrm{mg} \cdot \mathrm{L}^{-1}$ effective and those with $\mathrm{LC}_{50}>750 \mathrm{mg} . \mathrm{L}^{-1}$ inactive. Though, when we compare our result with the criterion of Komalamisra et al. ${ }^{45}$ our oil is classified as effective. 

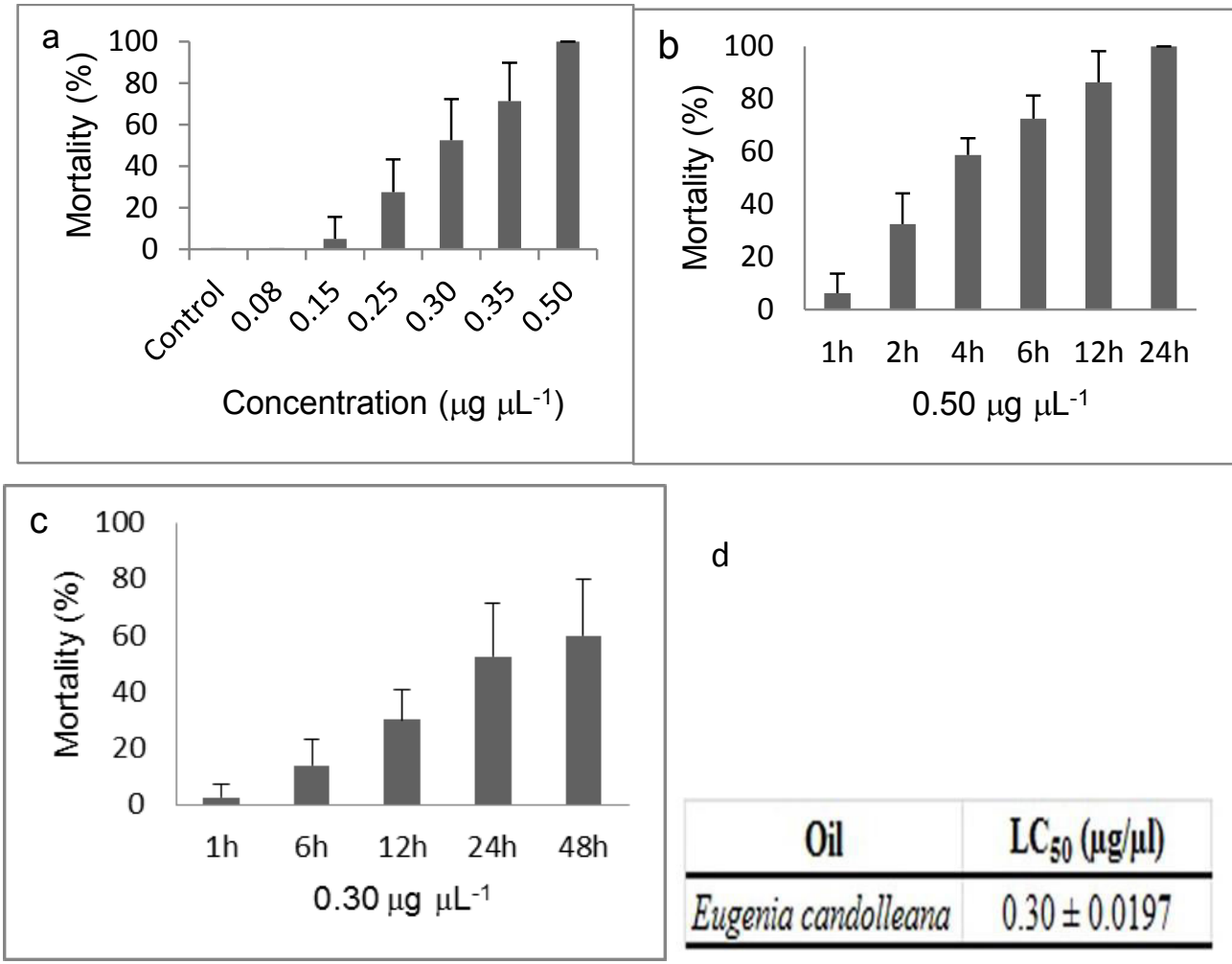

d

Figure 2. Larvicidal activity of Eugenia candolleana oil against the larvae of Aedes aegypti

\section{Conclusions}

The essential oil of Eugenia candolleana DC extracted by hydrodistillation showed a rich chemical profile in sesquiterpene hydrocarbons, introducing $\beta$-elemene as a major component. This is the first study of larvicidal activity against $A$. aegypti. Larvicidal activity can be attributed to the major component ( $\beta$-elemene), however more studies with this component are necessary to assign a synergistic or antagonistic effect of essential oil components. This essential oil showed larvicidal activity against $A$. aegypti. The potential lethality of the essential oil, may represent a new possibility for obtaining an active natural product to combat the mosquito that transmits yellow fever and dengue.

\section{Acknowledgements}

The authors are grateful to Fundação Chagas Filho de Amparo à Pesquisa do Estado do Rio de Janeiro (FAPERJ) Coordenação de Aperfeiçoamento de Pessoal de Nível Superior (CAPES), Conselho Nacional de Desenvolvimento Científico e Tecnológico (CNPq), and Instituto Nacional de Ciência e Tecnologia-Entomologia Molecular (INCT-EM) for scholarships and financial support.

\section{References}

${ }^{1}$ Vega-Rúa, A.; Lourenço-de-Oliveira, R.; Mousson, L.; Vazeille, M.; Fuchs, S.; Yébakima, A.; Gustave, J.; Girod, R.; Dusfour, I.; Leparc-Goffart, I.; Vanlandingham, D. L.; Huang, Y. J.; Lounibos, L. P.; Mohamed Ali, S.; Nougairede, A.; de Lamballerie, X.; Failloux, A. B. Chikungunya virus transmission 
potential by local Aedes mosquitoes in the Americas and Europe. PLOS Neglected Tropical Disease 2015, 9, 1. [CrossRef] [PubMed]

${ }^{2}{ }^{2}$ World Health Organization. A global brief on vector-borne diseases. WHO, Geneva. 2014. [Link]

${ }^{3}$ Dharmagadda, V. S. S.; Naik, S. N.; Mittal, P. K.; Vasudevan, P. Larvicidal activity of Tagetes patula essential oil against three mosquito species. Bioresource Technology 2005, 96, 1235. [CrossRef] [PubMed]

${ }^{4}$ Shaalan, E. A. S.; Canyon, D.; Younes, M. W. F.; Abdel-Wahab, H.; Mansour, A. H. A review of botanical phytochemicals with mosquitocidal potential. Environment International 2005, 31, 1149. [CrossRef] [PubMed]

${ }^{5}$ Prophiro, J. S.; Silva, M. A. N.; Kanis, L. A.; Silva, B. M.; Duque-Luna, J. E.; Silva, O. S. Evaluation of time toxicity, residual effect, and growth- inhibiting property of Carapa guianensis and Copaifera sp. in Aedes aegypti. Parasitology Research 2012, 110 , 713. [CrossRef] [PubMed]

${ }^{6}$ Krishnappa, K.; Elumalai, K.; Dhanasekara, S.; Gokulakrishran, J. Larvicidal and repellent properties of Adansonia digitata against medically important human malarial vector mosquito Anopheles stephensi (Diptera: Culicidae). Journal of Vector Borne Diseases 2012, 49, 86. [PubMed]

77. Maia, M. F.; Moore, S. J.; Plant-based insect repellents: a review of their efficacy, development and testing. Malaria Journal. 2011, 10, 11. [CrossRef] [PubMed]

${ }^{8}$ Nakamura, M. J.; Monteiro, S. S.; Bizarri, C. H.B.; Siani, A. C.; Ramos, M. F.S.; Essential oils of four Myrtaceae species from the Brazilian southeast. Biochemical Systematics and Ecology 2010, 38, 1170. [CrossRef]

${ }^{9}$ Guimarães, A. G.; Melo, M. S.; Bonfim, R. R.; Passos, L. O.; Machado, S. M. F.; Ribeiro, A. S.; Sobral, M.; Thomazzi, S. M.; QuintansJúnior, L. J.; Antinociceptive and antiinflammatory effects of the essential oil of Eugenia candolleana DC., Myrtaceae, on mice Revista brasileira de Farmacognosia. 2009, 19, 883. [CrossRef]

${ }^{10}$ SAS version 9.0, SAS Institute Inc., Cary, NC, USA, 2002.
${ }^{11}$ Van Den Dool, E.; Kratz, P. A. A generalization of the retention index system including liner temperature programmed gasliquid partition chromatography. Journal Chromatography 1963, 11, 463. [CrossRef]

${ }^{12}$ Adams, R. P.; Identification of Essential Oil Components by Gas Chromatography/Mass Spectrometry, 4th ed.; Allured Pub. Corp.: Illinois, 2007.

${ }^{13}$ National Institute of Standards and Technology (NIST); NIST/EPA/NIH: Search/Analysis Program and Data (Nist 08); Shimadzu Corp. Japão, 2008.

${ }^{14}$ World Health Organization. Guidelines for laboratory and field testing of mosquito larvicides. WHO, Geneva. 2005. [Link]

${ }^{15}$ World Health Organization. Dengue: guidelines for diagnosis, treatment, prevention and control. WHO, Geneva, 2009a. [Link]

${ }^{16}$ World Health Organization. Temephos in drinking-water: use for vector control in drinking-water sources and containers. WHO, Geneva, 2009b. [Link]

${ }^{17}$ BioStat professional 5.8 .0 (2008)

${ }^{18}$ Douglas, M. H.; Van Klink, J. W.; Smallfield, B. M.; Perry, N. B.; Anderson, R. E.; Johstone, P.; Weavers, R. T. Essential oils from New Zeland manuka: triketone and other chemotypes of Leptospermum scoparium. Phytochemistry 2004, 65, 1255. [CrossRef] [PubMed]

${ }^{19}$ Ramos, M. F. S.; Monteiro, S. S.; Silva, V. P.; Nakamura, M. J.; Siani, A. C. Essential oils from Myrtaceae species of the Brazilian southeastern maritime forest (restinga). Journal of Essential Oil Research 2010, 22, 109. [CrossRef]

${ }^{20}$ Apel, M. A.; Sobral, M.; Henriques, A. T.; Menut, C.; Bessière, J. M. Chemical composition of the essential oils from Southern Brazilian Eugenia species. Part III. Journal of Essential Oil Research 2002, 14, 290. [CrossRef]

${ }^{21}$ Brun, G. R.; Mossi, A. J. Caracterização química e atividade antimicrobiana do óleo volátil de pitanga (Eugenia uniflora L.) Perspectiva 2010, 34, 135. [Link]

${ }^{22}$ Stefanello, M. É. A.; Wisniewski JR, A.; Simionatto, E. L.; Cervi, A. C. Composição química e variação sazonal dos óleos 
essenciais de Eugenia pyriformis (Myrtaceae). Latin American Journal of Pharmacy 2009, 28, 449. [Link]

${ }^{23}$ Chantraine, J. M.; Laurent, D.; Ballivian, C.; Saavedra, G.; Ibañez, R.; Vilaseca, L. A. Insecticidal activity of essential oils on Aedes aegypti larvae. Phytoterapy Research 1998, 12, 350. [CrossRef]

${ }^{24}$ Aguilera, L.; Navarro, A.; Tacoronte, J. E.; Leyva, M.; Marquetti, M. C.; Efecto letal de myrtaceas cubanas sobre Aedes aegypti (Diptera: Culicidae). Revista Cubana de Medicina Tropical 2003, 55, 100. [PubMed]

${ }^{25}$ Cavalcanti, E. S. B.; Morais, S. M.; Lima, M. A. A.; Santana, E. W. P. Larvicidal activity of essential oils from Brazilian plants against Aedes aegypti L. Memórias do Instituto Oswaldo Cruz 2004, 99, 541. [CrossRef]

${ }^{26}$ Costa, J. G. M.; Rodrigues, F. F. G.; Angélico, E. C.; Silva, M. R.; Mota, M. L.; Santos, N. K. A.; Cardoso, A. L. H.; Lemos, T. L. G. Chemical- biological study of the essential oils of Hyptis martiusii, Lippia sidoides and Syzigium aromaticum against larvae of Aedes aegypti and Culex quinquefasciatus. Revista Brasileira de Farmacognosia 2005, 15, 304. [CrossRef]

${ }^{27}$ Amer, A.; Mehlhorn, H. Larvicidal effects of various essential oils against Aedes Anopheles and Culex larvae (Diptera, Culicidae). Parasitology Research 2006, 99, 466. [CrossRef] [PubMed]

${ }^{28}$ Lucia, A.; Gonzalez, A. P.; Seccac1ini, E.; Licastro, S.; Zerba, E.; Masuh, H. Larvicidal effect of Eucalyptus grandis essential oil and turpentine and their major components on Aedes aegypti larvae. Journal of the American Mosquito Control Association 2007, 3, 299. [CrossRef] [PubMed]

${ }^{29}$ Lucia, A.; Licastro, S.; Zerba, E.; Masuh, H. Yield, chemical composition, and bioactivity of essential oils from 12 species of Eucalyptus on Aedes aegypti larvae. Entomologia Experimentalis et Applicata 2008, 129, 107. [CrossRef]

${ }^{30}$ Cheng, S. S.; Chang, H. T.; Lin, C. Y.; Chen, P. S.; Huang, C. G.; Chen, W. J.; Chang, S. T. Insecticidal activities of leaf and twig essential oils from Clausena excavata against Aedes aegypti and Aedes albopictus larvae.
Pest Management Science 2009, 65, 339. [CrossRef] [PubMed]

${ }^{31}$ Mora, F. D.; Avila, J. L.; Rojas, L. B.; Ramirez, R.; Usubillaga, A.; Segnini, S.; Carmona, J.; Silva, B. Chemical composition and larvicidal activity of Eugenia triquetra essential oil from Venezuelan Andes. Natural Product Communications 2010, 5, 965. [PubMed]

${ }^{32}$ Park, H. M.; Kim, J.; Chang, K. S.; Kim, B. S.; Yang, Y. J.; Kim, G. H.; Shin, S. C.; Park, I. K. Larvicidal activity of Myrtaceae essential oils and their components against Aedes aegypti, acute toxicity on Daphnia magna, and aqueous residue. Journal of Medical Entomology 2011, 48, 405. [CrossRef] [PubMed]

${ }^{33}$ Lucia, A.; Juan, L. W.; Zerba, E. N.; Harrand, L.; Marcó, M.; Masuh, H. M. Validation of models to estimate the fumigant and larvicidal activity of Eucalyptus essential oils against Aedes aegypti (Diptera: Culicidae). Parasitology Research 2012, 110, 1675. [CrossRef] [PubMed]

${ }^{34}$ Tennyson, S.; Samraj, D. A.; Jeyasundar, D.; Chalieu, K. Larvicidal efficacy of plant oils against the dengue vector Aedes aegypti (L.) (Diptera: Culicidae). Middle-East Journal Science Research 2013, 13, 64. [CrossRef]

${ }^{35}$ Dias, C. N.; Moraes, D. F. Essential oils and their compounds as Aedes aegypti L. (Diptera: Culicidae) larvicides: review. Parasitology Research 2014, 113, 565. [CrossRef] [PubMed]

${ }^{36}$ Sukumar, K.; Perich, M. J.; Boobar, L. W. Botanical derivatives in mosquito control: a review. Journal of the American Mosquito Control Association 1991, 7, 210. [PubMed]

${ }^{37}$ Regnault-Roger, C. The potential of botanical essential oils for insect pest control. Integrated Pest Management Reviews 1997, 2, 25. [CrossRef]

${ }^{38}$ Magalhaes, L. A. M.; Lima, M. da P.; Marques, M. O. M.; Facanali, R.; Pinto, A. C. da S.; Tadei, W. P. Chemical composition and larvicidal activity against Aedes aegypti larvae of essential oils from four Guarea species. Molecules 2010, 15, 5734. [CrossRef] [PubMed] 
${ }^{39}$ Aciole, S. D. G.; Piccoli, C. F.; Duquel, J. E.; Costa, E. V.; Navarro-Silva, M. A.; Marques, F. A.; Maia, B. L. N. S.; Pinheiro, M. L. B.; Rebelo, M. T. Insecticidal activity of three species of Guatteria (Annonaceae) against Aedes aegypti (Diptera: Culicidae). Revista Colombiana de Entomología 2011, 37, 262. [Link]

${ }^{40}$ Lima, M. A. A.; de Oliveira, F. F. M.; Gomes, G. A.; Lavor, P. L.; Santiago, G. M. P.; NagaoDias, A. T.; Arriaga, Â. M. C.; Lemos, T. L. G.; de Carvalho, M. G. Evaluation of larvicidal activity of the essential oils of plants species from Brazil against Aedes aegypti (Diptera: Culicidae). African Journal of Biotechnology 2011, 10, 11716. [CrossRef]

${ }^{41}$ Simas, N. K.; Lima, E. C.; Conceição, S. R.; Kuster, R. M.; Oliveira-Filho, A. M. Produtos naturais para o controle da transmissão da dengue-atividade larvicida de Myroxylon balsamum (óleo vermelho) e de terpenóides e fenilpropanóides. Química Nova 2004, 27, 46. [CrossRef]

${ }^{42}$ Waliwitiya, R.; Kennedy, C. J.; Lowenberger, C. A. Larvicidal and ovipositionaltering activity of monoterpenoids, transanethole and rosemary oil to the yellow fever mosquito Aedes aegypti (Diptera: Culicidae).
Pest Management Science. 2009, 65, 241. [CrossRef] [PubMed]

${ }^{43}$ Cheng, S. S.; Chang, H. T.; Chang, S. T.; Tsai, K. H.; Chen, W. J. Bioactivity of selected plant essential oils against the yellow fever mosquito Aedes aegypti larvae. Bioresource Technology. 2003, 89, 99. [CrossRef] [PubMed]

${ }^{44}$ Massebo, F.; Tadesse, M.; Bekele, T.; Balkew, M.; Gebre-Michael, T. Evaluation on larvicidal effects of essential oils of some local plants against Anopheles arabiensis Patton and Aedes aegypti Linnaeus (Diptera, Culicidae) in Ethiopia. African Journal of Biotechnology 2009, 8, 4183. [Link]

${ }^{45}$ Komalamisra, N.; Trongtokit, Y.; Rongsriyam, Y.; Apiwathnasorn, C. Screening for larvicidal activity in some Thai plants against four mosquito vector species. The Southeast Asian Journal of Tropical Medicine and Public Health 2005, 36, 1412. [PubMed] ${ }^{46}$ Kiran, S. R.; Bhavani, K.; Devi, P. S.; Rao, B. R. R.; Reddy, K. J. Composition and larvicidal activity of leaves and stem essential oils of Chloroxylon swietenia DC against Aedes aegypti and Anopheles stephensi. Bioresource Technology 2006, 97, 2481. [CrossRef] [PubMed] 